HUDRON K. KARI,

Federal University Otuoke (Bayelsa State, Nigeria)

e-mail: karih@fuotuoke.edu.ng, ORCID0000-0001-7475-5172

\title{
LIBRARIES AND MOBILE TECHNOLOGIES: AN ASSESSMENT OF THE DEPLOYMENT OF MOBILE TECHNOLOGIES IN LIBRARIES OF NIGERIA
}

In this study, the researcher examined the views of library users and professional regarding the deployment of mobile technologies in libraries. The researcher tested five hypotheses to achieve the study objectives. The survey research design was used for the study. A total of 250 librarians and 250 library users in Nigeria constituted the sample for the study. The sample was purposively selected. The librarians were from Federal and state University owned libraries in Nigeria. The library users were undergraduates from University of Nigeria, Nsukka. A self-developed questionnaire served as the instrument for data collection. It was decided that a questionnaire was appropriate for the study because it aided the researcher to gather primary data in large volume. The response format for the questionnaire instrument was multiple option for the demographics and a four-point Likert scale for the psychographic response. Therefore, the questionnaire was divided into part $A$ and part $B$. While the former sought demographic data, the later sought psychographic data. A total of three experts from the Federal University Otueke validated the questionnaire. The researcher requested the experts to examine the instrument with specific considerations on clarity, appropriateness and logicality of presentation. The test retest approach was used to determine the reliability of the instrument. Both descriptive and inferential statistics were used to analyse the results of the study. All the five assumptions were not supported $(p>0.05)$. Therefore, the researcher conclude that both library users and professionals are aware of mobile technologies, ready to apply them in library services, and are influenced by perceived ease of usage and perceived usefulness. These results offer strong support for the Technology Acceptance Model. The results also have implications on the delivery of library services in the $21^{\text {st }}$ century library environment by implying that both library users and professionals will be willing to support any policy and programme aimed at promoting the application of mobile technologies in library practice and patronage. The basic contribution of this study is that it has offered empirical insights regarding the views of library users and professionals on library practice. This knowledge could guide policy advocacy monitoring and implementation. Based on the results of this study, it is recommended that libraries in Nigeria should fully integrate mobile technologies in their services and practice. It is also recommended that libraries should carry out studies that offer them insights into the mobile technologies preference of their target patrons so as to serve them better. Also, further studies are recommended to examine the level of implantation of mobile technologies in academic libraries in Nigeria. Finally, studies should be expanded to provide insight into the challenges against the implementation of mobile technologies in libraries in Nigeria. The practical and theoretical implications of the results have been explored.

Keywords: library; mobile technologies; professionals; users.

\section{Introduction}

Libraries are currently facing new challenges in a bid to deliver services to their users. Unlike in the past where users visited the libraries to make use of printed materials with the assistance of library attendants, the story has changed as the library of the $21^{\text {st }}$ century have more expectations from their users than even as recent as 10 years ago. The library of the $21^{\text {st }}$ century are driven by new technologies. It is gradually becoming impossible to deliver effective library services without applying technologies. Bucciarelli (2017) corroborates that the nature of libraries have changed significantly. Aslam (2018) avers that the changes that have taken place within the terrains of academic libraries have had an essential impact on library professionals such that it has affected their leadership styles as well as managerial decisions. Michalak
(2012) also adds that those who make use of the library have equally changed what their expectations of libraries are. In particular, Michalak holds that new technologies are now driving changes in the libraries.

In contemporary library services, users have the options of using different search engines along with different digital technologies. Libraries of the current millennium are confronted with high demand for technology among users. Librarians have to satisfy that need in order to encourage patronage of libraries. Satisfying user demands for technologies could also make library experience interesting.

Mobile technologies are now regarded as essential appurtenances for delivering library services to users. Mobile technologies describe hardware and software features of communication technologies. These technologies are regarded as mobile because they can be carried 
along from one place to another. People virtually carry their mobile phones with them everywhere-to the toilet, to the bedroom, in churches, on transit, to their dining tables, among others. Aharony (2014) is of the view that the features of mobile technologies are smallness of size and portability. He listed examples of mobile devices included tablets, smartphones, and netbooks. In the views of Aharony, such mobile technologies have completely changed the communication landscape. Mobile technologies have led to what is now called mobile libraries. The concept describes the supply of library services with the use of mobile devices. In the opinion of Speight (2009), the growing utilization of mobile devices in different spheres of life is leading libraries to contemplate adapting these new technologies. Lippincott (2010) corroborates that it is now important for libraries to deliver contents to their users through devices that they (the users) consider suitable to them. Bridges, Rempel, and Griggs (2010) say the time is apt for libraries to fully harness; the opportunities are inherent in mobile technologies. Hahn (2008) says that mobile technologies could be useful for libraries to deliver efficient, effective and timely services to their users.

Mobile technologies are easily accessible by those who possess them. Okoro and Gever (2018) reveal that the mobile phone technology has become common in contemporary society to the extent that its possession has continued to increase yearly. The Mobile phone technology has changed from being a status symbol to become an important item that almost everybody must have. The difference could be the quality of the mobile phone technology. Evidence in literature assertion on the importance of mobile phone is supported by evidence in literature (e.g. Chatterjee 2014; Khayyat \& Heshmati 2013; Mojaye, 2015; Sahota \& Kameswari, 2014) suggests that mobile phone technologies are now part and parcel of our daily lives. The Horizon Report (2009) regards mobile technologies as presenting express platforms to render education related services to learners in new fashion that they can hardly resist. The Horizon Report adds that mobile technologies will find a way to penetrate the heart of those who may be averse to visiting libraries and eventually compel them to access and use library features. As far back as 2008 , there was $61 \%$ mobile phone penetration rate globally with 4 billion users. The report adds that while many voice calls were made, users of mobile phones exchanged about 2.3 million text messages among themselves. Nigeria is one of the countries with speedy increase in mobile phone penetration figure. Examples of library services that can be offered to user through mobile technologies include notification services with the use of SMS, distance learning otherwise called e-learning, data browsing, the use of mobile interfaces for the purposes of eresources, supply of mobile document, among others.

The Pew Research Center (2016) in a study where 45,435 in 40 nations were examined reported Smartphone ownership rates gone up in many countries since 2013. A break down further revealed that more than 25 percentage points among the total population in large emerging economies such as Chile $(+26)$; Brazil $(+26)$; Turkey $(+42$ points), Malaysia $(+34)$ and South Korea were found to have with the highest number of smartphone ownership as up to $88 \%$ of respondents reported ownership of one. In Nigeria, the Nigerian Communication Commission (2018) reveals that the number of active mobile phone numbers in Nigeria went up to 146 million in January 2018, an evidence of an increase of 2,233,467 numbers from 144,631 in December 2017. Such overwhelming accepting of the mobile phone technologies has implications on library practice and in the delivery of such services to the patrons.

Mobile technologies could be useful in promoting efficiency in the delivery of library services. Saxena and Yadav (2013) opine that mobile technology could be beneficial to libraries by improving on the relationship that they have with users as well as offering them a variety of contents. In their views, through mobile technology features libraries that provide users with different options in the range of services that they provide. In the views of Singh (2013) Mobile devices could be helpful for establishing relationships with library users. This, according to Singh, could be done with the use of library application ("app") or mobile Web site that give users the leeway to have access to library hours facilities during working hours, see their library accounts, or even look for databases in a manner that is faster and easier too (see also: Barile, 2010; Booth, 2009; Hahn, 2008; Hanson, 2011).

With mobile technologies, library patrons now have the option of having mobile libraries if its features are well utilized. Maideen (2017) says that mobile technologies have given rise to what is called "Libraries in hand" scenario. This is because with effective utilization of mobile technologies, users can now have access to library services on 24 hours basis. The researcher adds that libraries can provide effective services to their users through mobile technologies. This, he adds can be done through the provision of mobile access to features such as journal publications, published text books, videos with education contents, audio books, as well as other multi-media contents. With mobile technologies, the audio/video collections of libraries have been expanded beyond the hitherto physical units where users visit to borrow books instead, users now have the option to stream on demand or download such contents. What this means is that users may not need to be physically present at libraries before they could use such features. Such an arrangement has the possibility of increasing the circulations and use of library materials. It is essential to add here that most users of mobile technologies are people within the learning age. Thai is to say that those who use sophisticated smartphones are normally young population who are also likely to have a need to visit the library for one reason or the other.

The applications of mobile technologies in libraries have been studied Singh (2013) examined the application of mobile technologies in academic libraries and mobile technologies have the potentials of making the delivery of library services more flexible. He reported further that mobile technologies could make it possible for users to continue to demand for library services. The result of Singh only suggests the promise of mobile technologies but if such dreams are to be come to reality, then libraries must take some critical decisions and make fundamental changes. This, in his views, include carrying out preliminary studies to ascertain mobile technologies use pattern among library users, train and retrain manpower that could be competent enough to handle issues related to mobile technologies vis-a-vis library services. Other steps, according to Singh include readiness to form working alliances with external bodies that could be useful in the attainment of the broader aim of using mobile technologies in libraries. Exploring new funding models and options, that will make the implementation of mobile technologies in libraries easier and faster. Finally, Singh found that willingness to make adjustments on the part of libraries is essential. Such adjustments are basically concern with compro- 
mising old ways of delivering library services to users to give room for the inclusion of mobile technologies.

Khatri and Gudadhe (2013) carried out a study with the objective to find out the perception of users regarding electronic publishing. The researcher found that library patrons use e-resources that are made available to them. The result further showed that such users make use of eresources in the comfort of their homes. The results further revealed high knowledge of new technologies among the sample studied. The study equally found high frequency of utilization of e-resources. This study is related to the current one because it offers insight into the views of library users regarding new technologies. This is more that eresources are typically those resources that are compatible with mobile technologies. Such resources are collections that can be accessed through technologies. They are mainly digital data. They could be packaged in different forms like texts, videos, and in a combination of both among others. Materials such as books, journals, image collection, among others can be part of e-resources (see also Satpathy \& Rout, 2010; Sharma, \& Sharma, 2010; Sharma, Chawla, \& Madaan, 2011; Shuva, \& Akhtar, 2011; Singh \& Arora, 2010; Swain \& Panda, 2009; Thanuskodi \& Ravi, 2011; Kari \& Oyeniran, 2019).

Aharony (2014) carried out a study to ascertain the use of mobile technologies by both library patrons and professionals. The result of this study showed that perceived ease of use and usefulness play critical roles in determining if library users and librarians use mobile technologies or not. In other words, when users and librarians perceive mobile technology as useful, they are likely to deploy them in utilizing library services than when they perceive them as not useful. Also, when users and librarians perceive mobile technologies as easy to use, it is likely to influence their usage than when they perceive such mobile technologies as not easy to use. Overall, Aharony's study supported the postulations of Technology Acceptance Model.

Ocran (2017) conducted a study with the aim of determining the perception of mobile library among students and library professionals. The researcher reported that most of the library users had access to mobile technology devices that could allow them access to library services. The results also showed that both library users and professionals reported readiness to use mobile technologies in accessing library services.

Overall, the researcher found positive perception regarding the application of mobile technologies in libraries by both library users and professionals. In this study, the Technology Acceptance Model of Davis (1986) was used to examine the use of mobile technologies in library services. The crux of TAM is how people accept and eventually use new technologies. Therefore, this study tested the following hypotheses:

H1: There is a significant difference in the mean scores of library users and professionals on the awareness level of mobile technologies that could be used to deliver library services.

H2: There is a significant difference in the mean scores of library users and professionals on readiness to utilize mobile technologies to deliver library services.
H3: Library users and professionals will significantly differ on the influence of Perceived ease on attitude towards mobile technologies.

H4: Library users and professionals will significantly differ on the influence of Perceived usefulness on attitude towards mobile technologies

H5: Library users and professionals will significantly differ on the influence of Perceived ease and perceived usefulness on intention to use mobile technologies.

\section{Materials and Methods}

For this study, descriptive survey research design was used. This design was regarded appropriate because the researcher sought to describe and explain mobile technologies and their use in libraries. A total of 250 librarians and 250 libraries users in Nigeria constituted the sample for the study. The sample was purposively selected. The librarians were from Federal and state University owned libraries in Nigeria. The library users were undergraduates from University of Nigeria, Nsukka. A self-developed questionnaire served as the instrument for data collection. It was decided that a questionnaire was appropriate for the study because it aided the researcher to gather primary data in large volume. The response format for the questionnaire instrument was multiple option for the demographics and a four-point Likert scale for the psychographic response. Therefore, the questionnaire was divided into part $A$ and part $B$. While the former sought demographic data, the later sought psychographic data. A total of three experts from the Federal University Otueke validated the questionnaire. I requested the experts to examine the instrument with specific considerations on clarity, appropriateness and logicality of presentation. The test retest approach was used to determine the reliability of the instrument. Therefore, initial 20 copies of the drafted questionnaire were administered to 20 persons in Enugu State. The researcher repeated this process after two weeks interval. The correlation coefficient calculation was .77 , an indication of high reliability of the instrument. I used descriptive statistics like simple percentage and mean to present the results of the study while inferential statistics like t-test was used to test the hypotheses postulated. All inferential statistics were tested at 0.05 level of significance. Also, all the analyses were done with SPSS version 22. I presented all the results in the tables.

\section{Results}

There was $100 \%$ return Rate for both library users and professionals for the questionnaire administered. That is to say that both library users and professionals return all the copies of the questionnaire that were administered. The $100 \%$ response rate could be because the researcher administered and retrieved the questionnaire copies instantly. The sample for library users was $67 \%$ male and $33 \%$ female. For library professionals, it was $64 \%$ male and $46 \%$ female. The mean age of library users was 23 (range 18 and 28 years) while that of library professionals was 43 (range 30 and 56 years). All the library users were single. However, $95 \%$ of the library professionals were married and only $5 \%$ were single.

Table 1: T-test analysis of library users and professionals on the awareness level of mobile technologies that could be used to deliver library services

\begin{tabular}{lccccccc}
\hline \multicolumn{1}{c}{ Grouping } & N & Mean & SD & t & Df & $\begin{array}{c}\text { Sig. } \\
\text { (2 tailed) }\end{array}$ & decision \\
\hline Users & 250 & 3.3 & .88 & & & & \\
Professionals & 250 & 3.2 & .62 & 9.561 & 651 & 0.62 & NS \\
\hline
\end{tabular}


Using the eyeball test, looking at the means reveals an insignificant difference in the sample means. Levene's test indicates by the $p$-value whether we should assume equal or unequal variances. If the $p$ value is $<0.05$ the evidence suggests that the variances are unequal. Here $p$
$=0.62$. Hence the equal variances assumed is $>0.005$, we accept the null hypothesis and conclude that there is no significant difference in the mean scores of library users and professionals on the awareness level of mobile technologies that could be used to deliver library services.

Table 2: T-test analysis of library users and professionals on readiness to use mobile technologies to deliver library services

\begin{tabular}{lccccccc}
\hline \multicolumn{1}{c}{ Grouping } & N & Mean & SD & t & Df & $\begin{array}{c}\text { Sig. } \\
(2 \text { tailed })\end{array}$ & decision \\
\hline Users & 250 & 3.5 & .68 & & & & \\
Professionals & 250 & 3.6 & .99 & 8.562 & 656 & 0.65 & NS \\
\hline
\end{tabular}

The table above was computed to ascertain the differences in the mean scores of both library users and library professionals on their readiness to use mobile technologies. The result showed that the $p$-value was more than the level of significance $(p>0.05)$. Therefore, the second assumption was not supported and we conclude that there is no significant difference in the mean scores of library users and professionals on readiness to utilize mobile technologies to deliver library services.

Table 3: T-test analysis of influence of Perceived ease of use on library users and professionals' attitude towards mobile technologies

\begin{tabular}{lccccccc}
\hline \multicolumn{1}{c}{ Grouping } & N & Mean & SD & t & Df & $\begin{array}{c}\text { Sig. } \\
\text { (2 tailed) }\end{array}$ & decision \\
\hline Users & 250 & 3.6 & .67 & & & & \\
Professionals & 250 & 3.7 & .91 & 7.562 & 654 & 0.64 & NS \\
\hline
\end{tabular}

Table three above sought to ascertain the influence of perceived ease of use mobile technologies on the attitudes of both library users and professionals. The result showed that the $p$-value was more than the level of significance $(p>0.05)$. Therefore, the third assumption was not supported and we conclude that there is no significant difference in the mean scores of library users and professionals on the influence of perceived ease of use and attitudes towards mobile technologies.

Table 4: T-test analysis of influence of perceived usefulness and ease of use on library users and professionals' intention to use mobile technologies

\begin{tabular}{lccccccc}
\hline \multicolumn{1}{c}{ Grouping } & N & Mean & SD & t & Df & $\begin{array}{c}\text { Sig. } \\
\text { (2 tailed) }\end{array}$ & decision \\
\hline Users & 250 & 3.5 & .97 & & & & \\
Professionals & 250 & 3.6 & .58 & 9.562 & 7.542 & 0.56 & NS \\
\hline
\end{tabular}

Table five above sought to ascertain the influence of perceived usefulness and ease of mobile technologies on the intention to use mobile technologies among both library users and professionals. The result showed that the $p$-value was more than the level of significance ( $>$ 0.05). Therefore, the last assumption was not supported and I conclude that there is no significant difference in the mean scores of library users and professionals on the influence of perceived usefulness and perceived ease of use mobile technologies and intention to use mobile technologies among library users and professionals.

\section{Discussion of Findings}

This study examined adoption and use of mobile technologies in libraries in Nigeria. The study tested five alternate hypotheses at 0.05 level of significance. In the first hypothesis, it was assumed that there is a significant difference in the mean scores of library users and professionals on the awareness level of mobile technologies that could be used to deliver library services. That assumption was not supported because the mean scores for both library users and library professionals was not significantly different. What this means is that both library users and library professionals were in agreement regarding their awareness level of mobile technologies that could be used in libraries. In the second hypothesis, it was assumed that there is a significant difference in the mean scores of library users and professionals on rea- diness to utilize mobile technologies to deliver library services. That assumption was also not supported. That is to say that both library users and professionals did not significantly differ in their mean scores regarding readiness to use mobile technologies. The results of our hypotheses one and two are consistent with that of Ocran (2017) who studies on the perception of mobile technologies could not find a significant difference in the responses of both library professionals and patrons.

In the third hypothesis, it was assumed that library users and professionals will significantly differ on the influence of Perceived ease on attitude towards mobile technologies. Again, that assumption was not supported as both library users and professionals did not significantly in their mean scores regarding the influence of perceived ease of use mobile technologies and attitudes towards them. What this means is that both library users and their professional counterparts are in agreement that their perception concerning the ease of use mobile technologies in libraries plays a role in deciding their attitude towards it. In the fourth hypothesis, it was assumed that library users and professionals will significantly differ on the influence of Perceived usefulness on attitude towards mobile technologies. That assumption was not supported. As both library users and professionals were of the view that perceived usefulness significantly influences attitudes towards mobile technologies. In the last hypothesis, it was assumed that library users and professionals will significantly differ 
on the influence of Perceived ease and perceived usefulness on intention to use mobile technologies. The assumption was equally not supported as both library users and library professionals were of the view that perceived ease of use and perceived usefulness significantly influences their intention to use mobile technologies. The results of hypotheses three to four are in consonance with that of Aharony (2014) whose study showed that perceived ease of use and perceived usefulness of mobile technologies significantly influence both library users and professionals alike. The result of this study also provide strong support for Davis's (1986) TAM which noted that perceived ease of use and perceived usefulness are essential considerations that determine acceptance and use of new technologies.

\section{Conclusion/Recommendations}

In this study the researcher tested five hypotheses to provide evidence regarding the views of library users and professionals on mobile technologies and their application in library services. All the five assumptions were not supported. Therefore, the researcher conclude that both library users an professionals are aware of mobile technologies, ready to apply them in library services, and are influenced by perceived ease of use and perceived usefulness. These results offer strong support for the Technology Acceptance Model. The results also have implications on the delivery of library services in the $21^{\text {st }}$ century library environment by implying that both library users and professionals will be willing to support any policy and programme aimed at promoting the application of mobile technologies in library practice and patronage. The basic contribution of this study is that it has offered empirical insights regarding the views of library users and professionals on library practice. This knowledge could guide policy advocacy monitoring and implementation. Based on the results of this study, it is recommended that libraries in Nigeria should fully integrate mobile technologies in their services and practice. It is also recommended that libraries should carry out studies that offer them insights into the mobile technologies preference of their target patrons so as to serve them better. Also, further studies are recommended to examine the level of implantation of mobile technologies in academic libraries in Nigeria. Finally, studies should be expanded to provide insight into the challenges against the implementation of mobile technologies in libraries in Nigeria.

\section{REFERENCES}

Aharony, N. (2014). Mobile libraries: Librarians' and students perspectives. Retrieved from https://pdfs.semanticscholar.org/ c48a/a87a47cc485-12e50b851fc555774e82e7c33.pdf

Aslam, M. (2018). Current trends and issues affecting academic libraries and leadership skills, Library Management, 39 (1/2), 78-92. DOI: https://doi.org/10.1108/LM-10-2016-0076

Barile, L. (2010). Mobile technologies for libraries: a list of mobile applications and resources for development, College \& Research Libraries News, 72(4), 222-228.

Booth, C. (2009). Information innovation: Tracking student interest in emerging library technologies at Ohio University. ACRL Report. Retrieved from http://www.ala.org/ala/mgrps/ divs/acrl/ publications/ digital/ii-booth.pdf

Bridges, L., Rempel, H. \& Griggs, K. (2010). Making the case for a Fully mobile library web site: From floor maps to the catalog, Reference Services Review, 38, (2), 309-320.

Bucciarelli, E. R. (2017). Expanding the repertoire: The changing nature of work and roles of the academic library liaison. University Library Faculty Scholarship. 28.

Chatterjee, S. (2014). A sociological outlook of mobile phone use in society. International Journal of Interdisciplinary and Multidisciplinary Studies, 1(6), 55-63.

Hahn, J. (2008). Mobile learning for the twenty-first century librarian, Reference Services Review, 36 (3), 272-88.

Hahn, J. (2008). Mobile learning for the twenty-first century librarian, Reference Services Review, 36(3), 272-288.

Hanson, C. W. (2011). Libraries and the Mobile Web. Library Technology Reports, 47(2), 12-22.

Kari, H., \& Oyeniran, G. (2019). Promoting Library Services in the Social Media Era: Exploring Use, Objectives, Challenges and Perceived Influence. Skhid, 5(163), 60-66. DOI: http://dx.doi.org/ 10.21847/1728-9343.2019.5(163).180787

Khatri, A. \& Gudadhe, V. (2013). Use and user perception of E-Resources in SRC Ayurvedic Mahavidyalaya, Chikhli: A study. International Journal of Digital Library Services, 3 (4), 47-58.

Khayyat, N., \& Heshmati, A. (2013). Determinants of mobile telecommunication adoption in Kurdistan. International Journal of Communication, 7, 2285-2311.

Lippincott, J. (2010). A mobile future for academic libraries, Reference Services Review, 38 (2), 205-213.

Maideen, S. (2017). Mobile Technologies for Academic Libraries: An Overview. Emerging Trends in Library and Information Science, 124-129.

Michalak, S. (2012). This changes everything: Transforming the academic library. Journal of Library Administration, 52, 411-423.

Mojaye, E. (2015). Mobile phone usage among Nigerian university students and its impact on teaching and learning. Global Journal of Arts Humanities and Social Sciences, 3(1), 29-38.

Ocran, T. (2017). Perception of students on mobile technology based library services. Library Philosophy and Practice (e-journal). 1802.

Okoro, N. \& Gever, V. C. (2018). Gender differentials in mobile phone communication pattern among youth: Evidence from a qualitative study. Nsukka Journal of Foreign languages and Library Studies, 1, 133-143.

Pew Research Centre (2016). Smartphone Ownership and Internet Usage Continues to Climb in Emerging Economies But advanced economies still have higher rates of technology use. Retrieved from http://www.pewglobal.org/files/2016/02/pew research_center_global_technology_report_final_february_22_2016.pdf

Sahota, C., \& Kameswari, V. (2014). Mobile phones for agricultural extension in North India. Malaysian Journal of Media Studies, 16 (1), 1-11.

Satpathy, S. \& Rout, B. (2010). Use of e-resources by the faculty members with special references to CVRCE, Bhuvaneshwar. DESIDOC Journal of Library and Information Technology, 30, 11-16.

Saxena, A. \& Yadav, R. (2013). Impact of mobile technology on libraries: a descriptive study. International Journal of Digital Library Services, 3 (4), 1-13.

Sharma, C. \& Sharma, R. (2010). Perception of eresources among faculty members of National Institute of Technology (NIT) Kurukshetra, SRELS Journal of Information Management, 47, 297-305.

Sharma, U. C., Chawla, R. \& Madaan, P. (2011).Internet usage by the faculty members and the students in professional colleges at Mathura region: An empirical study. International Journal of Information Dissemination and Technology, 1, 77-85.

Shuva, N. Z. \& Akhtar, R. (2011). Internet usage by the students of Faculty of Arts of University library of Dhaka (Bengladesh). Pearl: Journal of Library \& Information Science, 5, 14-22.

Singh, G. \& Arora, T. (2010). Usage of e-resources in college libraries in Delhi. Library Herald, 48, 363-375. 
Singh, N. D. (2014). Using mobile technologies in libraries and information centers", Library Hi Tech News, 31(5), 14-16. DOI: https://doi.org/10.1108/LHTN-05-2014-0034

Speight, S. (2009). M-libraries: Libraries on the move to provide virtual access. Retrieved from www.ariadne.ac.uk/issue61/ speight-rvw/
Swain, D. K. \& Panda, K. C. (2009). Use of e-services by faculty members of business schools in a state of India: A study. Collection Building, 28(3), 108-16.

Thanuskodi, S. \& Ravi, S. (2011). Use of digital resources by Faculty and research scholars of Manonmaniam Sundaranar University, Tirunelveli. DESIDOC Journal of Library \& Information Technology, 31, 25-30.

Хадрон К. Карі,

Федеральний університет Otиоке (Байєлса, Нігерія)

e-mail: karih@fuotuoke.edu.ng,ORCID 0000-0001-7475-5172

\section{БІБЛІОТЕКИ ТА МОБІЛЬНІ ТЕХНОЛОГІї: ОЦІНКА ВПРОВАДЖЕННЯ МОБІЛЬНИХ ТЕХНОЛОГІЙ У БІБЛІОТЕКАХ НІГЕРІЇ}

У статті проаналізовано думку користувачів і фахівців бібліотек Нігерії щодо розгортання мобільних технологій в цій сфері. Для проведення дослідження було розроблено спеціальний інструментарій, що враховує демографічні та психографічні показники. В цілому було опитано 250 бібліотекарів та 250 користувачів бібліотек у Нігерії. Для визначення надійності інструментарію був використаний метод повторного тестування. В ході дослідження було висунуто і перевірено п'ять гіпотез. Всі п'ять припущень не підтвердилися (p>0,05). Таким чином, автор прийшов до висновку, що і користувачі, і фахівці бібліотек багато знають про мобільні технології, готові застосовувати їх в бібліотечних службах і усвідомлюють переваги передбачуваної простоти використання й передбачуваної корисності. Ці результати свідчать про необхідність активного впровадження в бібліотечну справу мобільних технологій. Результати дослідження також впливають на надання бібліотечних послуг в бібліотечному середовищі XXI ст., оскільки передбачають, що як користувачі, так i фахівці бібліотеки підтримуватимуть будь-яку політику і програму, спрямовані на сприяння застосуванню мобільних технологій в бібліотечній практиці й патронажі. Основне значення даного дослідження полягає в тому, що воно дало емпіричну інформацію про погляди користувачів і фахівців бібліотеки на бібліотечну практику. Ці знання можуть направляти моніторинг і реалізацію адвокації політики. Ґрунтуючись на результатах цього дослідження, розроблені рекомендації щодо інтеграції мобільних технологій в послуги і практики африканських бібліотек. Також рекомендується, щоб бібліотеки проводили дослідження, які дають їм уявлення про переваги мобільних технологій їх цільових клієнтів, щоб краще обслуговувати їх. У подальших дослідженнях рекомендується вивчити рівень впровадження мобільних технологій в академічні бібліотеки Нігерії. Більш того, на думку авторів, подібні дослідження мають бути розширені, щоб надати уявлення про упередженість проти впровадження мобільних технологій в бібліотеках Нігерії.

Ключові слова: бібліотека; мобільні технології; фрахівці; користувачі.

(c) Hudron K. Kari

Надійшла до редакції: 02.01.2020

Прийнята до друку: 17.01.2020 